\title{
Delikaat: 10 liefdesverse (van 20)
}

Ek loer deur 'n skrefie,

sien jou,

sien jou siel in reënboogkleure glans,

broos,

broos soos skulpvlerke,

'n flikkering van lig,

atome wat dans.

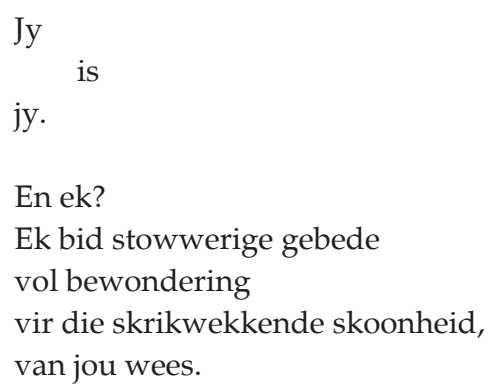

En ek?

Ek bid stowwerige gebede

vol bewondering

vir die skrikwekkende skoonheid,

van jou wees.

Die skemerdag sterf stadig,

langsaam,

kleurryk.

Ons bly roerloos sit;

ek en jy,

vingers vervleg,

oë op die see,

woordeloos verweef in mekaar.

'n Tydlose aanraking,

binne die spieëlgladde sfeer

van hierdie perfekte moment,

wat skielik genadeloos

drup

in die kosmiese dam.

Menswees
menswees
saamwees
menswees.

Vir jou, maak ek die aarde toe in 'n bont kniekombersie,

bêre ek al die oopgemaakte Vrydae in 'n satynhoutkissie,

drup ek lemoenheuning in die droë, smaaklose gesprekke.

\author{
Vir jou, verf ek seemeeue op die kaal, \\ maanverligte golwe, \\ plant ek koorsboomwoude tussen \\ spiralende sterrestelsels, \\ neurie ek simfonieë in verlate \\ sandwoestyne.
}

Vir jou, versamel ek kinderlaggies in ruwe erdekanne,

kweek ek vlinderkleure in

kristalglashuise,

dans ek stoomwarm spore oor

brosgerypte grasvelde.

Vir my; steek jy 'n kers op,

bak jy 'n brood,

snoei jy 'n boom.

'n Engel is jy nie,

want dié sluimer vlerkloos

in kits kinderhemele.

Nee, jy is ' $n$ walvis,

'n krilvreter,

een, wat diep wegsink,

neerdaal uit die koninkryk van die son,

na donker, saamgepersde dieptes,

waar jou lewensliedere

geduldig wag,

die woordelose klankkettings

wat jy

oor oseane heen

uitkreet

na my.

Soggens sluip jy skugter terug uit die jagveld van jou drome,

jou sagte oë vol vreemde sien en

verwegwees.

-Waar was jy?- fluister ek.

Jy kyk skaam weg,

verleë omdat daar in die kokon van

jou slaap,

slegs plek is vir een.
Ek trek jou slaaplyf styf teen my vas, soen jou agter jou oor,

want ek weet,

al reik die sydraad van jou drome tot aan die anderkant van die heelal, bly jou lyf steeds geanker, in die oseaan van my hart.
Al die kerke,
katedrale,
sinagoges,
tempels,
tabernakels,
en moskees
sal toemaak,
en toebly,
die dag as almal
soos jy;
kan oopmaak,
kan aanraak,
kan vashou
en kan gee.

Brood my saggies

my liefste botter-botter-bek,

bêre my binne,

bietjies-bietjies binne,

babatjie fyn,

breekbaar en broos.

Bondel my, brei my, buffer my, bou my, bossiekop, Berber, breekbaar en broos.

Begeer my, beleër my, baal my en bloei my, bietjies-bietjies binne, breekbaar en broos.

Jy bemin my oop,

oop

oop

sonkind,

oop

oop

oop,

soos 'n skoenlapperkerk. 
Uit al die sandemmers vol dae, uit al die donskomberse van sterre, uit al die melkweë van gene, uit al die dryfhout van kontinente, uit al die oseane van mense, het jy besluit om op hierdie dwarrelende weg langs my te loop.

Waarom?
Ek sleep my lomp letters op 'n hoop, maak bakhand woorde bymekaar, poog om iets te sê oor jou; $j y$, wat my geleende seepbel vul, met sin en sekerheid.

Tevergeefs...

In jou hierwees skuil die heelal se diepste geheime.

Klip en ek praat klip, geologie met mekaar, knars stowwerig deur die millennia. En jy?
Jy vleg jou skraal vingers deur grasvelde en kinderhare, lag speels boom-op, giggel vir stokou sterre en 'n verrimpelde maan.

Meer tyd, smeek ek, gee meer tyd, want die sonryp liefde in jou oë, kan ek nog steeds nie verstaan nie. Meer tyd! 